\title{
Universiteit
}

Leiden

The Netherlands

\section{Sexual Orientation Discrimination in the European Union: National Laws and the Employment Equality Directive \\ Waaldijk, C.; Bonini-Baraldi, M.T.}

\section{Citation}

Waaldijk, C., \& Bonini-Baraldi, M. T. (2006). Sexual Orientation Discrimination in the European Union: National Laws and the Employment Equality Directive. The Hague: T.M.C. Asser Press.

Retrieved from https://hdl.handle.net/1887/16528

Version: $\quad$ Not Applicable (or Unknown)

License: $\quad$ Leiden University Non-exclusive license

Downloaded from: $\quad$ https://hdl.handle.net/1887/16528

Note: To cite this publication please use the final published version (if applicable). 


\section{Sexual Orientation Discrimination}

IN THE EUROPEAN UNION:

National Laws and the Employment Equality Directive 
Discrimination based on [...] sexual orientation may undermine the achievement of the objectives of the EC Treaty, in particular the attainment of a high level of employment and social protection, raising the standard of living and the quality of life, economic and social cohesion and solidarity, and the free movement of persons.

Employment Equality Directive, recital 11 


\title{
Sexual Orientation Discrimination IN THE EUROPEAN UNION: \\ National Laws and THE \\ Employment Equality Directive
}

\author{
by \\ Kees WaALdijK \\ and \\ Matteo Bonini-Baraldi
}

$\mathrm{T} \cdot \mathrm{M} \cdot \mathrm{C} \cdot$ ASSER PRESS

The Hague 
Published by T.M.C.ASSER PRESS

P.O.Box 16163, 2500 BD The Hague, The Netherlands

$<$ www.asserpress.nl>

T.M.C.ASSER PRESS' English language books are distributed exclusively by:

Cambridge University Press, The Edinburgh Building, Shaftesbury Road,

Cambridge CB2 2RU, UK,

or

for customers in the USA, Canada and Mexico:

Cambridge University Press, 100 Brook Hill Drive, West Nyack, NY 10994-2133, USA

$<$ www.cambridge.org>

ISBN 10: 90-6704-213-7

ISBN 13: 978-90-6704-213-0

All rights reserved.

(C) 2006, T.M.C.AsSER PRESS, The Hague, The Netherlands and the authors

No part of the material protected by this copyright notice may be reproduced or utilized in any form or by any means, electronic or mechanical, including photocopying, recording, or by any information storage and retrieval system, without written permission from the copyright owner. 


\section{Summary contents}

Acknowledgements

VII

Contents

IX

List of tables

XIV

List of abbreviations

$\mathrm{XV}$

Chapter 1 Introduction

Chapter 2 The Employment Equality Directive and other aspects of European law

Chapter 3 General situation with respect to sexual orientation discrimination at national level

Chapter 4 Comparative analysis of legislation implementing the Directive in the fifteen old Member States

Chapter 5 Implementation of the Directive in the ten new Member States and in the two acceding countries

Chapter 6 Overview of the state of implementation of the Directive

Chapter 7 Conclusions

Annex Council Directive 2000/78/EC of 27 November 2000 establishing a general framework for equal treatment in employment and occupation

Bibliography

European and international case law

European Community legislation

Index 



\section{Acknowledgements}

For their help and support in the completion of this book we are deeply indebted to many. It is with a touch of pride that we say this, because we firmly believe in the benefits that collaborative research can offer to the advancement of our understanding of legal phenomena.

From Brussels, the European Commission provided funding for the establishment of the European Group of Experts on Combating Sexual Orientation Discrimination, which we have jointly coordinated at the Universiteit Leiden. Without this funding (under the Community Action Programme to Combat Discrimination 2001-2006) we would never have been able to pool together the wealth of expertise and dedication that enabled the group to produce its report, on which this book is based. The Commission's Anti-Discrimination Unit supported the activities of the Group and, through Cécile Le Clercq and Álvaro Oliveira, closely followed the writing and editing of the report and helped us through the many intricacies of performing a contract with the Commission. It goes without saying that neither the report nor this book necessarily reflects the opinion or position of national authorities or of the European Commission.

We are grateful to the national experts that were part of the Group of Experts, that existed from 2002 to 2004: Helmut Graupner, Olivier De Schutter, Søren Baatrup, Rainer Hiltunen, Daniel Borrillo, Susanne Baer, Matthaios Peponas, Mark Bell, Stefano Fabeni, Anne Weyembergh, Miguel Freitas, Ruth Rubio-Marín, Hans Ytterberg and Robert Wintemute. We are equally indebted to those who joined our efforts at a later stage for all of their voluntary work. This informal network was composed of: Mihaela Preslavska, Haris Kountouros, Lucie Otáhalová, Juris Lavrikovs, Christian Attard, Krzysztof Smiszek and Iustina Ionescu. It is only thanks to the competence, passion and patience of all of them that we are now able to present this book.

At the Faculty of Law of the Universiteit Leiden, our comparative study of the implementation of the Employment Equality Directive was part of the research programme Securing the Rule of Law in a World of Multi-Level Jurisdiction of the E.M. Meijers Institute of Legal Studies.

In Leiden, staff of the Meijers Institute supported us in coordinating the activities of the Group and in overcoming the inevitable difficulties we faced. We would like to mention especially: Riekje Boumlak, secretary to the project, Alan Littler, researcher, Erik Kien, financial adviser, Wout Morra, Caroline 
Koetsenruijter and Loes Amperse, research assistants, and Stephen Moran, research assistant and language editor. To all of them, to the T.M.C. Asser Press and to the many other people who helped us complete this book, we wish to express our deepest and sincerest gratitude.

Leiden/Bologna, January 2006

Kees Waaldijk, Matteo Bonini-Baraldi

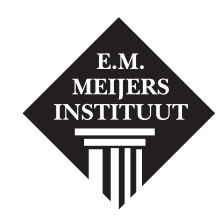

INSTITUUT VOOR

RECHTSWETENSCHAPPELIJK 


\section{Contents}

Acknowledgements

$\begin{array}{lll}\text { List of tables } & \text { XIV }\end{array}$

$\begin{array}{ll}\text { List of abbreviations } & \text { XV }\end{array}$

1 Introduction 1

2 The Employment Equality Directive and other aspects of European law 5

2.1 General legal situation 5

2.1.1 Constitutional protection against discrimination 5

2.1.2 General principles and concepts of equality 9

2.1.3 Provisions on sexual orientation discrimination in employment $\begin{array}{ll}\text { or occupation } & 17\end{array}$

2.1.4 Important case law precedents on sexual orientation discrimination in employment or occupation 21

2.1.5 Provisions on discrimination in employment or occupation that do not (yet) cover sexual orientation 23

2.1.6 Provisions on sexual orientation discrimination in other fields than employment and occupation $\quad 24$

$\begin{array}{ll}2.1 .7 & \text { Other aspects of the legal background } \\ 28\end{array}$

2.2 The prohibition of discrimination required by the Directive 30

2.2.1 Instrument(s) used to implement the Directive 30

2.2.2 Concept of sexual orientation (article 1) 32

2.2.3 Direct discrimination (article 2(2)(a)) 33

2.2.4 Indirect discrimination (article 2(2)(b)) 34

2.2.5 Prohibition and concept of harassment (article 2(3)) 35

2.2.6 Instruction to discriminate (article 2(4)) 36

2.2.7 Material scope of the applicability of the prohibition (article 3) 36

2.2.8 Personal scope of applicability: natural and legal persons whose actions are the object of the prohibition 37

2.3 What forms of conduct in the field of employment are prohibited as sexual orientation discrimination?

2.3.1 Discrimination on grounds of a person's actual or assumed heterosexual, homosexual or bisexual preference or behaviour

2.3.2 Discrimination on grounds of a person's coming out with, or not hiding, his or her sexual orientation

2.3.3 Discrimination between same-sex partners and different-sex partners 
2.3.4 Discrimination on grounds of a person's association with LGB individuals, events or organisations

2.3.5 Discrimination against groups, organisations, events or information of/for/on LGB individuals

2.3.6 Discrimination on grounds of a person's refusal to answer, or answering inaccurately, a question about sexual orientation

2.3.7 Discrimination on grounds of a person's previous criminal record due to a conviction for a homosexual offence without heterosexual equivalent

2.3.8 Harassment

2.4 Exceptions to the prohibition of discrimination 48

2.4.1 Objectively justified indirect disadvantages (article 2(2)(b)(i)) 48

2.4.2 Measures necessary for public security, for the protection of rights of others, etc. (article 2(5))

2.4.3 Social security and similar payments (article 3(3)) 49

2.4.4 Occupational requirements (article 4(1)) 49

2.4.5 Loyalty to the organisation's ethos based on religion or belief (article 4(2))

2.4.6 Positive action (article 7(1)) 51

2.5 Remedies and enforcement 51

2.5.1 Basic structure of enforcement of employment law $\quad 51$

2.5.2 Specific and/or general enforcement bodies 52

2.5.3 Civil, penal, administrative, advisory and/or conciliatory procedures (article 9(1))

2.5.4 Civil, penal and/or administrative sanctions (article 17) 52

2.5.5 Natural and legal persons to whom sanctions may be applied 54

2.5.6 Awareness among law enforcers of sexual orientation issues $\quad 54$

2.5.7 Standing for interest groups (article 9(2)) 54

2.5.8 Burden of proof of discrimination (article 10) 55

2.5.9 Burden of proof of sexual orientation $\quad 55$

2.5.10 Victimisation (article 11) 56

2.6 Reform of existing discriminatory laws and provisions 56

2.6.1 Abolition of discriminatory laws and administrative provisions $\begin{array}{ll}\text { (article 16(a)) } & 57\end{array}$

2.6.2 Measures to ensure amendment or nullity of other discriminatory provisions (article 16(b)) 57

2.7 Concluding remarks

3 General situation with respect to sexual orientation discrimination at national level

$\begin{array}{lll}3.1 & \text { The social situation } & 61\end{array}$

$\begin{array}{ll}\text { 3.2 Constitutional protection against discrimination } & 67\end{array}$

3.3 Provisions on sexual orientation discrimination in employment 72 
3.4 Case law precedents on sexual orientation discrimination in employment

3.5 Provisions on discrimination in employment that do not cover sexual orientation

3.6 Provisions on sexual orientation discrimination in fields other than employment

3.7 Other aspects of the legal background

4 Comparative analysis of legislation implementing the Directive in the fifteen old Member States

4.1 Introduction 87

4.2 The prohibition of discrimination required by the Directive 91

4.2.1 Instrument(s) used to implement the Directive 91

4.2.2 Concept of sexual orientation (article 1) 94

4.2.3 Direct discrimination (article 2(2)(a)) 98

4.2.4 Indirect discrimination (article 2(2)(b)) 100

4.2.5 Prohibition and concept of harassment (article 2(3)) 102

4.2.6 Instruction to discriminate (article 2(4)) 104

4.2.7 Material scope of the applicability of the prohibition (article 3) 104

4.2.8 Personal scope of applicability: natural and legal persons whose actions are the object of the prohibition

4.3 What forms of conduct in the field of employment are prohibited as sexual orientation discrimination?

4.3.1 Discrimination on grounds of a person's actual or assumed heterosexual, homosexual or bisexual preference or behaviour

4.3.2 Discrimination on grounds of a person's coming out with, or not hiding, his or her sexual orientation

4.3.3 Discrimination between same-sex partners and different-sex partners

4.3.4 Discrimination on grounds of a person's association with LGB individuals, events or organisations

4.3.5 Discrimination against groups, organisations, events or information of/for/on LGB individuals

4.3.6 Discrimination on grounds of a person's refusal to answer, or answering inaccurately, a question about sexual orientation

4.3.7 Discrimination on grounds of a person's previous criminal record due to a conviction for a homosexual offence without heterosexual equivalent

4.3.8 Harassment

4.4 Exceptions to the prohibition of discrimination

4.4.1 Objectively justified indirect disadvantages (article 2(2)(b)(i))

4.4.2 Measures necessary for public security, for the protection of rights of others, etc. (article 2(5))

4.4.3 Social security and similar payments (article 3(3)) 
4.4.4 Occupational requirements (article 4(1))

4.4.5 Loyalty to the organisation's ethos based on religion or belief (article 4(2))

4.4.6 Positive action (article 7(1)) 129

4.4.7 Exceptions beyond the Directive 129

$\begin{array}{ll}\text { 4.5 Remedies and enforcement } & 130\end{array}$

4.5.1 Basic structure of enforcement of employment law $\quad 130$

4.5.2 Specific and/or general enforcement bodies 130

4.5.3 Civil, penal, administrative, advisory and/or conciliatory procedures (article 9(1))

4.5.4 Civil, penal and/or administrative sanctions (article 17) 134

4.5.5 Natural and legal persons to whom sanctions may be applied 137

4.5.6 Awareness among law enforcers of sexual orientation issues 138

4.5.7 Standing for interest groups (article 9(2)) 139

4.5.8 Burden of proof of discrimination (article 10) 141

4.5.9 Burden of proof of sexual orientation 141

4.5.10 Victimisation (article 11) 142

4.6 Reform of existing discriminatory laws and provisions 143

4.6.1 Abolition of discriminatory laws and administrative provisions (article 16(a))

4.6.2 Measures to ensure amendment or nullity of other discriminatory provisions (article 16(b)) 144

4.6.3 Discriminatory laws and provisions still in force 145

4.7 Concluding remarks

5 Implementation of the Directive in the ten new Member States and in the two acceding countries

5.1 Introduction

5.2 The prohibition of discrimination

5.2.1 Direct and indirect discrimination (article 2(2)) 154

5.2.2 Harassment (article 2(3)) and instruction to discriminate (article 2(4))

5.2.3 Material scope (article 3) 162

5.3 Exceptions

5.3.1 Measures necessary for public security, for the protection of rights of others, etc. (article 2(5))

5.3.2 Social security and similar payments (article 3(3)) 164

5.3.3 Occupational requirements (article 4(1)) and loyalty to the organisation's ethos based on religion or belief (article 4(2)) 165

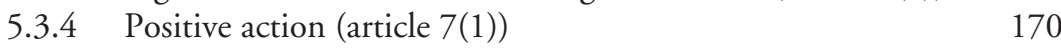

$\begin{array}{lll}5.4 & \text { Enforcement } & 171\end{array}$

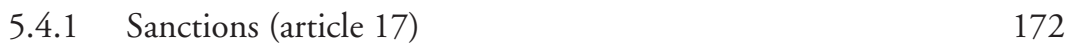

$\begin{array}{lll}\text { 5.4.2 Enforcement bodies } & 175\end{array}$

5.4.3 Burden of proof (article 10) and victimisation (article 11) 179

5.4.4 Standing for interest groups (article 9(2)) 183 
5.5 Case law on sexual orientation discrimination

6 Overview of the state of implementation of the Directive

6.1 Introduction

6.2 The timeliness of implementation

6.3 The quality of implementation

6.3.1 Prohibition of different forms of sexual orientation discrimination in employment

6.3.2 Exceptions to the prohibition of discrimination

6.3.3 Enforcement of the prohibition of discrimination

7 Conclusions

7.1 Two decades of changing law

7.2 Discrimination prohibited at many levels

7.3 The complementarity of discrimination prohibitions

7.4 The complexity of equality law

7.5 A certain implementation of the Directive

7.6 Legal uncertainty

7.7 The specific character of sexual orientation

7.8 Real legal certainty?

7.9 Law-making at many levels - inspiration and guidance

Annex Council Directive 2000/78/EC of 27 November 2000 establishing a general framework for equal treatment in employment and occupation 221

Bibliography

European and international case law 


\section{List of tables}

Table 1 The non-acceptance of homosexual people according to the European Values Study Surveys

Table 2 The acceptance of homosexuality according to the European Values Study Surveys

Table 3 The level of opposition against (sexual orientation) discrimination according to the 2002 Eurobarometer

Table 4 The extent of perceived sexual orientation discrimination according to the 2002 Eurobarometer

Table 5 Provisions on sexual orientation discrimination in employment

Table 6 Provisions on sexual orientation discrimination beyond employment

Table 7 Decriminalisation of homosexuality and legislative recognition of same-sex partners

Table 8 Major shortcomings in the implementation of the Directive 


\section{Abbreviations}

appl.

application number(s)

$\mathrm{COM}$

documents of the Commission of the European Communities

Directive (the) Council Directive 2000/78/EC of 27 November 2000 establishing a general framework for equal treatment in employment and occupation (the Employment Equality Directive)

EC European Community, European Communities, or Treaty Establishing the European Community

ECHR Convention on the Protection of Human Rights and Fundamental Freedoms (the European Convention on Human Rights)

ECJ Court of Justice of the European Communities

ECR European Court Reports

ECSC European Coal and Steel Community

ECtHR European Court of Human Rights

EEC European Economic Community

EU Charter European Union Charter of Fundamental Rights

Euratom European Atomic Energy Community

ILGA International Lesbian and Gay Association

LGB lesbian, gay and/or bisexual

OJ L Official Journal of the European Communities (L Series)

OJ C Official Journal of the European Communities (C Series)

para. $\quad$ paragraph(s) 
